\title{
7
}

\section{ACEsso à Justiça no Brasil}

\author{
Access to justice in Brazil
}

\section{José SoAres Filho}

Juiz do Trabalho aposentado. Mestre e doutor em Direito pela UFPE. Professor da Universidade Católica de Pernambuco e da Escola Superior da Magistratura Trabalhista da $6^{\text {a }}$ Região. Membro efetivo do Instituto dos Advogados Brasileiros (Rio de Janeiro-RJ), do Instituto Latinoamericano de Derecho del Trabajo y de la Seguridad Social, da Academia Pernambucana de Letras Jurídicas, da Academia Pernambucana de Direito do Trabalho.E-mail: jose_soares_filho@hotmail.com

RECEBIDO EM: 26.12 .12

APROVADO EM: 20.02.13

\section{RESUMo}

A prestação jurisdicional é uma função indeclinável do Estado, que deve ser exercida com eficiência e a presteza capazes de atender à demanda social, crescente a cada dia. Para tanto, incumbe ao Estado prover, mediante pronta normatização e medidas administrativas, os meios de realizar tal prestação, e instituir órgãos e mecanismos com estrutura suficiente para lograr esse objetivo, efetivando os direitos dos cidadãos e reparando as lesões que venham a sofrer. Ao mesmo tempo, impõe-se garantir o acesso à justiça, que implica a assistência jurídica integral e gratuita por parte do poder público a todos os que dela necessitem, o que constitui um princípio constitucional. Nesse sentido, urge reformar a legislação processual, bem como os órgãos jurisdicionais, modernizando-os, atualizando seu funcionamento, para adaptá-los às circunstâncias emergentes, ante as constantes mutações e evolução das relações sociais. 
Palavras-chave: PrestaÇão jurisdicional. Acesso À Justiça. Assistência JURÍDICA. EFETIVAÇÃO DOS DIREITOS.

\section{Abstract}

The adjudication is an inalienable feature of the State, which must be performed with efficiency and promptness thus being able to meet social demands, which is increasing daily. For this purpose, the State must provide, by regulation and administrative measures, the means to make such provisions and to establish mechanisms and institutional bodies with enough structure to achieve this goal, which directly affects the rights of citizens, repairing the damage that they will suffer. At the same time, it must be ensured the access to justice, which implies the full and free legal assistance by the government to all who need it, a fundamental constitutional principle. In this sense, it is urgent to reform the procedural law and the courts and its organs, modernizing them, updating its operation, to adapt them to circumstances arising, in the face of constant change and evolution of social relations.

Key words: Judicial dispute Resolution. AcCess to justice. Legal aid. ENFORCEMENT OF RIGHTS.

SuMÁRIo: Introdução. 1. Garantia de acesso à justiça: assistência judiciária e justiça gratuita. 2. Mecanismos legais de acesso à justiça. 2.1 Os Juizados Especiais Cíveis e Criminais. 2.2 O procedimento sumaríssimo na Justiça do Trabalho. 2.3 As Comissões de Conciliação Prévia. Conclusão. Referências.

\section{INTRODUÇÃO}

O Estado tem a grave responsabilidade, para com os cidadãos, de prestar a jurisdição, da forma mais ampla e correta possível, que seja hábil à persecução do ideal de justiça. Ademais, essa prestação deve ser feita num espaço de tempo razoável, assegurando-se os meios que garantam a celeridade do respectivo processo (art. 5 ${ }^{\circ}$ LXXVIII, da Constituição de 1988). Da realização, em maior ou menor grau, desse desiderato depende sua credibilidade social e sua própria razão de ser como instituição comprometida com o bem comum, expressão da vontade geral, que ele encarna.

Essa função é exercida através de instrumentos estabelecidos pela ordem jurídica, que consubstanciam o direito positivo processual. Este é informado 
por princípios e rege-se por normas presentes na Constituição, assim como na legislação infraconstitucional. O processo judiciário, por conseguinte, haure seus fundamentos dos princípios e normas do direito constitucional, pois ele é quem legitima as regras disciplinadoras da prestação jurisdicional.

O Direito Processual, sem dúvida, assume considerável importância na aplicação do direito, porquanto cuida dos meios de que o Estado se utiliza, através dos órgãos que constituem o Poder Judiciário, para a prestação jurisdicional. Esta, no regime da legalidade e no sistema democrático de poder, é regulada por normas de ordem pública de origem legislativa, que prescrevem os atos mediante os quais se desenvolve o processo objetivando a adequação da lei ao caso concreto.

A moderna concepção do processo visa a transformá-lo, de simples instrumento de justiça, em garantia de liberdade. Esse, o seu sentido ético, profundamente influenciado por fatores históricos, sociológicos e políticos. Por isso, para o completo entendimento dele, como fenômeno, e de seus princípios, é indispensável considerar suas raízes constitucionais. Notadamente o direito processual penal, que é tido como direito constitucional aplicado às relações entre autoridade e liberdade.

No presente trabalho, trataremos, especificamente, da garantia do acesso à justiça, que implica a assistência jurídica integral e gratuita por parte do Estado, a todos os que dela necessitarem, o que constitui um dos princípios constitucionais (art. 5 , LXIV, da CF/88) atinentes ao direito processual.

\section{Garantia de aCESSo À JUSTIÇA: ASSistênCia JUdiciária E JUSTIÇA GRATUITA}

Para lograr o ambicioso e nobre objetivo de prestar a jurisdição, o Estado deve disponibilizar os meios hábeis, colocando-os ao alcance de todos os cidadãos, quaisquer que sejam suas condições socioeconômicas e culturais. Trata-se, pois, de abrir caminhos para o acesso fácil, amplo e irrestrito, aos órgãos do Poder Judiciário, assim como aos administrativos, pois estes também exercem a jurisdição. Ora, é óbvio que as dificuldades econômicas, sociais e culturais dificultam, ou impedem, essa aproximação, frustrando a solução de conflitos de interesses e a preservação ou a efetivação de direitos. Daí, ser imprescindível a assistência judiciária, assim como a gratuidade da justiça, para os cidadãos carentes de recursos econômicofinanceiros.

A instituição de assistência judiciária aos necessitados remonta à Constituição de 1934, que para isso criou órgãos especiais e assegurou a isenção de emolumentos, custas, taxas (art. 113, n. 32). Tal direito foi mantido na Constituição de 1967, com a Emenda de 1969 (art. 153, § 32). Através 
da Lei $\mathrm{n}^{\mathrm{o}}$ 1060, de 05.2.50, foi estabelecida a assistência judiciária aos necessitados, considerados como tais os que não disponham de meios para arcar com as despesas processuais, inclusive a de honorários advocatícios, sem prejuízo do sustento próprio ou da família. Tem um alcance geral, devendo ser prestada por advogado ligado a serviço de assistência judiciária organizado e mantido pelo Estado (Defensoria Pública), ou, não havendo, por advogado indicado pela $\mathrm{OAB}$, ou ainda, inexistindo no local representação da $\mathrm{OAB}$, por advogado nomeado pelo juiz, por indicação da própria parte ou pelo órgão de classe respectivo.

A Constituição de 1988 instituiu não só a assistência judiciária, mas também a jurídica (art. 5 LXXIV), o que significa que ela deve efetivar-se também no processo administrativo; e, nesse sentido, criou a Defensoria Pública (art. 143), para orientação jurídica e defesa dos necessitados, em todos os graus.

No âmbito da Justiça do Trabalho, aplica-se, desde 26.6.70, a Lei no 5.584, que atribui aos sindicatos de trabalhadores - ou, se não houver, aos promotores públicos ou defensores públicos -, a incumbência de prestar assistência judiciária gratuita a todo membro da categoria profissional respectiva (e não apenas aos sócios) cujo salário mensal não exceda o valor de três salários mínimos, ou, sendo superior, o obreiro declare, sob as penas da lei, não ter condição de arcar com as despesas processuais sem prejuízo do sustento próprio e de sua família. Nessa hipótese, sendo o empregado vencedor na causa, o juiz condena o empregador ao pagamento de honorários de advogado (honorários da sucumbência) para o sindicato, os quais, contudo, deverão reverter em proveito do advogado, ex vide do art. 23 da Lei ${ }^{\circ}$ 6.809/94.

Como informa Roberto Rosas ${ }^{551}$, a justiça gratuita surgiu com a Revolução Francesa, porém com a idéia de que a parte não recompensaria o juiz pela prestação jurisdicional, do que resultou a regra constitucional de que o juiz não terá participação nas custas.

A justiça gratuita implica a dispensa provisória de despesas processuais, pelo juiz, em favor daquele cujo estado socioeconômico não the permita demandar em juízo sem prejuízo do sustento próprio ou de sua família. Não se confunde com a assistência judiciária, que resulta de ordenamento estatal, com indicação de defensor, como esclarece Pontes de Miranda ${ }^{552}$. Constitui benefício decorrente da assistência judiciária de que trata a Lei n ${ }^{\circ} 1060 / 50$, como dispõe seu artigo $3^{\circ}$. No tocante à Justiça do Trabalho, está prevista no $\S 3^{\circ}$ do art. 790 da CLT, que faculta aos juízes do trabalho conceder, de ofício, o benefício da justiça gratuita, inclusive quanto a traslados e instrumentos, àqueles que

\footnotetext{
${ }^{551}$ In Direito Processual Constitucional - Princípios Constitucionais do Processo Civil. São Paulo: Edit. Rev dos Tribunais, 1999, p. 48.

${ }^{552}$ In Comentários à Constituição de 1969. São Paulo: Rev. dos Tribunais, 1970. p. 642.
} 
perceberem salário igual ou inferior ao dobro do mínimo legal, ou declararem, sob as penas da lei, que não estão em condições de pagar as custas do processo sem prejuízo do sustento próprio ou de sua família.

\section{Mecanismos legais de ACESSo À JUSTIÇA}

Quando se cuida desse tema, tem-se em vista a jurisdição estatal, não se considerando a que resulta de negociação entre os interlocutores sociais, no âmbito de suas relações privadas, traduzida em normas que visam a regular seus interesses socioeconômicos ${ }^{553}$.

O acessoà jurisdição estatal requer medidas que devem ser promovidas, em primeiro plano, pelo Legislativo, mediante leis que tornem realidade o princípio constitucional em comento, e, em segundo plano, pelo Executivo, através de atos que regulamentem e instrumentalizem as normas editadas a respeito. Essas providências já foram tomadas, com razoável amplitude, e constam, principalmente, da instituição dos Juizados Especiais Cíveis e Criminais no Judiciário Estadual (Lei no 9.099/95), do procedimento sumaríssimo perante a Justiça do Trabalho (Lei n ${ }^{\circ}$ 9.957/2000), das Comissões de Conciliação Prévia dos litígios trabalhistas (Lei n ${ }^{\circ}$ 9.958/2000) e, ultimamente, dos Juizados Especiais Federais Cíveis e Criminais (Lei n ${ }^{\circ}$ 10.259/2001).

\subsection{OS JUIZADOS ESPECIAIS CÍVEIS E CRIMINAIS}

Os juizados especiais estavam previstos, para o Distrito Federal, os Territórios e os Estados, no art. 98, I, da Constituição Federal de 1988, que estabeleceu para eles competência para a conciliação, o julgamento e a execução de causas cíveis de menor complexidade e infrações penais de menor potencial ofensivo, mediante os procedimentos oral e sumaríssimo, admitidos, nas hipóteses legais, a transação e o julgamento de recursos por turmas de juízes de primeiro grau. Em relação à Justiça Federal, sua criação foi disposta no parágrafo único daquele artigo, acrescentado pela Emenda Constitucional $\mathrm{n}^{\mathrm{o}} 22$, de 18.3.99.

A criação dos Juizados Especiais Cíveis e Criminais para as unidades federativas foi saudada, pela classe jurídica em geral, como um acontecimento notável, que representa uma das maiores conquistas do Judiciário brasileiro no último século. Isso por que:

\footnotetext{
${ }_{553}$ Vejam-se, a propósito, os acordos e convenções coletivos de trabalho, no campo das relações de trabalho, de que tratam os arts. 611 e segs. da CLT, e as convenções coletivas de consumo, previstas na Lei no 8.078/90 (Código de Defesa do Consumidor), art. 107.
} 
a) tendo os Juizados Cíveis competência para conciliar e julgar as causas cujo valor não exceda 40 salários mínimos e outras de pequeno porte, e os Juizados Criminais, competência dessa ordem em relação às infrações penais de potencial ofensivo menor, como tais considerados as contravenções penais e os crimes a que a lei comine pena máxima não superior a 1 (um) ano (excetuados os casos em que a lei preveja procedimento especial), é evidente que abrangem a maior parte das causas em um e outro campo, com vantagens de várias ordens para os jurisdicionados;

b) desafogam os órgãos judiciários já existentes, que, em outra situação, continuariam a receber uma sobrecarga de trabalho de grande monta (as causas cuja competência é atribuída aos Juizados Especiais representam, como já assinalado, a maior parte das que ordinariamente são levadas ao Judiciário);

c) as características do processo, em um e outro tipo de ação, conduzidos pelos critérios da oralidade, informalidade, economia processual e celeridade, objetivando, sempre que possível, no cível, a conciliação ou a transação, com a reparação dos danos sofridos pela vítima, no criminal, a aplicação de pena não privativa de liberdade, importam certamente em prestação jurisdicional oportuna e eficaz, evitando, consequentemente, sua morosidade, que é reconhecidamente um dos principais fatores de ineficiência dessa atividade, confirmando o jargão de que "justiça tardia é negação de justiça";

d) aproxima o Judiciário do cidadão comum, pela desburocratização ou simplificação dos serviços, admitindo, perante os Juizados Especiais Cíveis, o "jus postulandi" (dispensa da assistência por advogado) nas causas de até 20 salários mínimos, bem como proibindo a prisão em flagrante e a exigência de fiança se o autor do fato presumivelmente delituoso, após a lavratura do respectivo termo, for imediatamente encaminhado ao Juizado ou assumir o compromisso de a ele comparecer; e) facilita o acesso à justiça das camadas sociais economicamente menos favorecidas, porquanto institui a gratuidade do processo em primeiro grau de jurisdição, tratando-se dos Juizados Especiais Cíveis;

f) tem um efeito político salutar, pois atende ao superior interesse de uma prestação jurisdicional rápida e eficiente, concorrendo, destarte, para a paz e a estabilidade das relações sociais.

Com propriedade diz Marcelo Jodas Badaró (2000) que "estas particularidades transformam o JEC em uma espécie de protetor dos mais humildes, depositário de sua confiança", sem dispensar a imparcialidade que 
deve estar presente em todas as atividades do Judiciário em qualquer das áreas de sua atuação.

Tais são a importância e a utilidade desses Juizados, que eles serviram de modelo e parâmetro para outros ramos do Judiciário: no âmbito da Justiça do Trabalho, com o procedimento sumaríssimo, cujo projeto de lei se inspirou e se baseou na Lei n ${ }^{\circ}$ 9.099/95, no que tange aos Juizados Especiais Cíveis; na Justiça Federal, valendo como referencial, para a criação dos Juizados Especiais Federais.

Os Juizados Especiais Federais - Cíveis e Criminais -, no fundo, visam a atender aos mesmos objetivos que têm os da Justiça Estadual, isto é, agilização da prestação jurisdicional no concernente aos processos de menor expressão econômica e complexidade técnica, evitando que sejam levados aos Tribunais Regionais Federais e ao Superior Tribunal de Justiça, notoriamente assoberbados por milhares de feitos, como assinalou o Deputado Moroni Torgan, do PFLCeará (apud TOURINHO NETO, 2001) quando da aprovação, na Câmara dos Deputados, do projeto que se converteu na Lei $n^{\circ} 10.259 / 2001$, acrescentando que agora "teremos a chance de dar oportunidade às pessoas mais simples e carentes de terem solucionados seus problemas de modo sumaríssimo", o que "irá agilizar algum ganho que possam vir a ter e que, muitas vezes, levaria anos e anos para ser alcançado".

Esse diploma legal tem peculiaridades que o distinguem da Lei n ${ }^{\circ}$ 9.099/95 (Juizados Especiais dos Estados): a) compete aos Juizados Especiais Federais Cíveis processar, conciliar e julgar as causas de competência da Justiça Federal até o valor de 60 salários mínimos, ao passo que, naqueles, o teto é de 40 salários mínimos; b) os federais têm como parte contrária sempre uma pessoa jurídica de direito público, enquanto dos estaduais são excluídas as pessoas jurídicas de direito público, assim como as empresas públicas da União; c) no que tange à matéria criminal, são da competência dos Juizados Especiais Federais processar e julgar os feitos da competência da Justiça Federal pertinentes às infrações de menor potencial ofensivo, quais sejam os crimes a que a lei comine pena máxima não superior a dois anos, ou multa, eis que nos estaduais a competência se circunscreve a crimes para os quais a lei estipule pena de, no máximo, 1 (um) ano.

E apresenta vantagens dignas de nota, tais como: a) elimina o duplo grau de jurisdição, ou seja, a remessa, que é obrigatória no juizado ordinário (art. 475 do CPC); b) permite o cumprimento da sentença independentemente de precatório; c) a Fazenda Pública é igualada às demais partes, sem o privilégio de prazo em dobro para recorrer e em quádruplo para contestar.

A propósito dos Juizados Especiais Federais - o que pode ser aplicado, com propriedade, aos Juizados Especiais Estaduais -, Tourinho Neto (2012) adverte que o juiz deve ser humilde, paciente, dotado de sensibilidade, paixão, bem como da disponibilidade para ouvir. "Não deve ser uma máquina de 
solucionar conflitos, mas um homem; não sentir-se um simideus ou deus, mas preocupar-se com seu semelhante em solucionar seus conflitos". Prossegue, dizendo: "Deve o juiz abandonar o tecnicismo, o formalismo exagerado, as sentenças recheadas de erudição". E conclui, em tom de exortação: "Devemos lutar para mudar a mentalidade de nossos julgadores".

Segundo a Lei $n^{\circ} 10.259 / 01$, art. 1º aplica-se aos Juizados Especiais Cíveis e Criminais da Justiça Federal, no que não conflitar com essa lei, o disposto na Lei n ${ }^{\circ}$ 9.099/95, que trata dos Juizados Especiais Cíveis e Criminais Estaduais.

Em sentido inverso, entendem alguns juristas que, consoante a Lei 10.259/01, aplica-se, em parte, aos Juizados Especiais Cíveis e Criminais de âmbito estadual o critério estabelecido nos Juizados Especiais Federais no tocante ao limite de pena para estabelecer a competência do Juizado ( $§$ único do art. $2^{\circ}$ ), ou seja, teria revogado o art. 61 da Lei $n^{\circ}$ 9.099/95, ampliando para 2 (dois) anos o limite de pena ali fixado a esse respeito, porque não seria jurídico distinguir o tratamento penal dispensado aos autores de crimes idênticos tãosomente em razão da competência para processar e julgar o delito.

Esse é o entendimento de Danni Sales Silva (2001), o qual afirma que o $\S$ único do art. $2^{\circ}$ da Lei $n^{\circ} 10.259 / 01$ derrogou a parte final do art. 61 da Lei $n^{\circ}$ 9.099/95, ampliando o conceito de crime de pequeno potencial ofensivo, pelo que passaria à competência dos Juizados Especiais Criminais, tanto no plano federal, quanto no estadual, conciliar, julgar e executar os crimes a que a lei comine pena de até 2 (dois) anos, ressalvando, porém, que se manteve inalterado o art. 89 da Lei ${ }^{0}$ 9.099/95, o qual estabelece que a suspensão condicional do processo se restringe aos crimes a que corresponde pena igual ou inferior a 1 (um) ano.

Todavia, outros estudiosos e operadores do direito opinam pela não aplicabilidade da Lei $n^{\circ} 10.259 / 01$ no plano estadual. É, por exemplo, o ponto de vista de Paulo Martini (2002), o qual expressa que, com o advento da referida lei, "passamos a contar no Brasil, com dois conceitos de infração de menor potencial ofensivo, um federal e outro estadual", eis que "o Poder Constituinte quis instituir Juizados distintos e dotados de leis diferentes".

Incisivo, nessa linha de raciocínio, é o pronunciamento de Antônio Carlos de V. Coelho Barreto Campello (2002), para quem a lei, considerando de forma distinta - em relação à competência da Justiça Federal e à da Justiça Estadual $^{554}$ - as infrações de menor potencial ofensivo, não afronta o princípio constitucional da isonomia, pois "a isonomia consiste exatamente em tratar diferentemente os que se encontrem em situações distintas". Aduz Barreto Campello (2002) que "a fixação da competência da Justiça Federal leva em consideração, primordialmente, a qualidade da vítima (União, autarquias

\footnotetext{
${ }_{554}$ Observe-se, por oportuno, que o julgamento das contravenções é da exclusiva competência da Justiça Estadual, ainda que firam interesse da União, como reza a Súmula no 38 do STJ.
} 
e empresas públicas) e que essa qualidade é frequentemente valorada pela legislação para aquilatar a resposta penal aos delitos", motivo por que ela atribui aos crimes praticados contra esses órgãos tratamento distinto do que é dispensado aos crimes perpetrados contra outros entes públicos, assim como (acrescente-se) os de direito privado.

Com o objetivo de melhorar a prestação jurisdicional e, paralelamente, facilitar o acesso à justiça, os Tribunais de Justiça de alguns Estados têm criado órgãos para tratar de questões específicas, o que é sumamente louvável. Em Pernambuco há o Juizado Especial do Consumidor, Juizados da Criança e do Adolescente, Juizados da Mulher, Juizado do Torcedor (funcionando nos estádios de futebol), Juizado dos Delitos de Trânsito (itinerante), Juizado das questões marítimas (criado recentemente em função da instalação e funcionamento do Complexo Portuário de Suape), Vara das Penas Alternativas, além de um serviço de assistência social às crianças e adolescentes carentes (Projeto Criança Cidadã), um centro de tratamento dos dependentes químicos (Centro de Justiça Terapêutica), ambos fruto da operosa administração e notável sensibilidade do Des. Nildo Nery quando presidente do TJ. Na Paraíba, o TJ instalou, além de outras especializadas, Vara Privativa de Questões Agrárias, dando cumprimento ao disposto no art. 126 da CF/88.

\subsection{O Procedimento Sumaríssimo na Justiça do Trabalho}

Foi instituído pela Lei $\mathrm{n}^{\circ} 9.957 / 2000$, com o objetivo de tornar mais ágil, simples e eficiente o processo trabalhista, compreendendo as causas cujo valor não exceda 40 salários mínimos, que representam a grande maioria das lides submetidas à apreciação da Justiça do Trabalho.

De observar que o processo trabalhista comporta, fundamentalmente, dois tipos de procedimentos: o comum e o especial. O especial abrange: a) ação de consignação em pagamento (CPC, arts. 890/900); b) o inquérito judicial para apurar falta grave imputada a empregado estável (CLT, arts. $853 / 855)$; c) as medidas cautelares previstas no art. 659, IX e X, da CLT - a primeira, visando a tornar sem efeito transferência de empregado; a segunda, objetivando reintegrar no emprego dirigente sindical afastado, suspenso ou dispensado pelo empregador; d) o mandado de segurança (Lei n ${ }^{\circ} 1533 / 51$ ); o dissídio coletivo (CLT, art. 856/875). O comum subdivide-se em ordinário, sumário e sumaríssimo.

A Lei no 9.957/2000 reproduz, em vários de seus dispositivos, a Lei $n^{\circ}$ 9.099/95, instituidora dos Juizados Especiais Cíveis e Criminais nos Estados, que, como assinalado atrás, se qualificam como medidas legislativas caracterizadoras de grande avanço no ordenamento jurídico pátrio, no sentido 
de sua modernização e aperfeiçoamento. Porém, ao seguir os passos da Lei $\mathrm{n}^{\mathrm{o}}$ 9.099/95 quanto aos Juizados Especiais Cíveis, o legislador perdeu um pouco de vista as especificidades técnicas e ideológicas do processo trabalhista.

Aplicam-se ao procedimento sumaríssimo, como fontes subsidiárias, a Consolidação das Leis do Trabalho, a Lei n ${ }^{\circ}$ 9.099/95 no tocante aos Juizados Especiais Cíveis e o próprio Código de Processo Civil.

O procedimento sumaríssimo estabelece audiência única, que já faz parte da estrutura do procedimento ordinário, quer o trabalhista, quer o cível, o qual atende aos princípios de concentração e celeridade dos atos processuais; contudo, sem infraestrutura necessária para que se efetive tal sistemática (Varas especiais ou aumento do número das atuais), ou seja, não se criaram juizados especiais trabalhistas.

Vários dispositivos dele que visam a simplificar e agilizar o processo estão fadados a inaplicabilidade, porquanto não encontram respaldo na realidade - o legislador, ao que parece, ignorou-a, talvez pensando que, por meio de simples terminologia (sumaríssimo), pudesse alterar a natureza ou a essência das coisas, sobrepor-se às forças da realidade, como observa Manuel Antônio Teixeira (2000:9) (exemplos: os arts. 852-B, II e III, 852-C, 852-G, 852-H e $\S \S 1^{\circ}$ e $7^{\circ}$ ).

A lei $9.957 / 2000$ representa tímido avanço no sentido da melhoria da prestação jurisdicional no âmbito da competência dos órgãos da Justiça do Trabalho. O legislador perdeu boa oportunidade de aperfeiçoar essa prestação, elevando o ordenamento jurídico trabalhista ao nível de diplomas legais de vanguarda sob esse aspecto, tal como o Código de Defesa do Consumidor, que institui a inversão do ônus da prova em favor do consumidor, como meio de facilitar a defesa de seus direitos, quando, a critério do juiz, for verossímil a alegação ou quando ele for hipossuficiente, observando-se as regras ordinárias da experiência (inciso VIII do artigo $6^{\circ}$ da Lei $n^{\circ} 8.078$, de 11.9.90).

A essas observações críticas, feitas por ManoelAntônio Teixeira, Francisco Antônio de Oliveira (2000, p. 8/11) acrescenta, dentre outras, as seguintes: a) a lei em referência, dada a ausência de intimidade do legislador com o tema de que trata, agiliza o processo em primeira instância, mas não o consegue no âmbito recursal; b) perdeu-se oportunidade de fixar a alçada em sede executória. Ora, mesmo nos processos cujas ações tenham como valor da causa quantia não superior a 2 (dois) salários mínimos - de cuja decisão, na fase de conhecimento, não cabe recurso ordinário -, pode-se utilizar, na fase de execução, o recurso de agravo de petição; c) desperdiçou-se, também, a oportunidade de impedir, nos processos em rito sumaríssimo, a ação rescisória ou a ação anulatória; d) o legislador, ao editar a referida lei, esqueceu-se de dar condições para a sua implementação criando, concomitantemente, varas especializadas em primeiro grau e turmas especializadas nos Tribunais Regionais. 
A par dessas deficiências, houve avanços consideráveis, em relação ao processo trabalhista, com a Lei no 9.957/2000, em termos de celeridade, simplificação, presteza e eficácia.

São pressupostos do procedimento sumaríssimo (arts. 852-A e 852-B, da CLT):

a) valor da causa até 40 salários mínimos;

b) exclusão das demandas em que seja parte a Administração Pública direta, autárquica e fundacional;

c) pedido líquido, certo e determinado;

d) indicação do nome e endereço corretos do reclamado.

\section{Questões polêmicas:}

1) $\mathrm{O}$ art. 852-B, $\S 1^{\circ}$, impõe, como consequência do não atendimento de requisitos da petição inicial - pedido certo ou determinado e líquido; indicação, pelo autor, do nome e endereço corretos do reclamado -, o arquivamento da reclamação e condenação do autor ao pagamento de custas sobre o valor da causa. Tal efeito é compatível com nosso ordenamento processual comum, que prevê o indeferimento da petição inicial por falta de requisito legal (art. 295 do CPC).

Todavia, há entre os juslaboristas quem advogue outra solução, que evita o arquivamento da petição, com duas alternativas, que seriam mais consentâneas com o princípio da economia processual: uma, prevista no art. 284 do CPC, consistente em dar oportunidade ao autor para emendar ou completar a petição; outra, em recebê-la pelo rito ordinário.

2)Questiona-se a permanência do procedimento especial-denominado sumário - previsto no art. $2^{\circ}, \S \S 3^{\circ}$ e $4^{\circ}$, da Lei $n^{\circ} 5.584 / 70$, que diz respeito às ações em que o valor da causa não ultrapasse 2 (dois) salários mínimos. Somos da opinião de que não há incompatibilidade na vigência concomitante de ambos os diplomas legais, embora o procedimento sumaríssimo englobe as ações compreendidas na abrangência do procedimento sumário. Ora, neste há para os reclamantes duas vantagens em relação ao procedimento sumaríssimo, quais sejam: a) no sumário é dispensável o resumo, na ata de audiência, dos depoimentos, devendo constar dela apenas a conclusão do Juiz quanto à matéria de fato, ao passo que no sumaríssimo devem ser registrados, ainda que resumidamente, os atos essenciais, inclusive as afirmações fundamentais das partes e as informações úteis à solução da causa; b) no sumário, salvo se versarem sobre matéria constitucional, nenhum recurso cabe das sentenças proferidas nos dissídios de sua alçada, restrição essa que inexiste no procedimento sumaríssimo. 


\subsection{As Comissões de Conciliação Prévia}

Trata-se de órgãos de solução extrajudicial dos litígios trabalhistas, que podem ser enquadrados no âmbito da jurisdição privada. Foram instituídos pela Lei n ${ }^{\circ}$ 9.958/2000.

Sua criação era reclamada há bastante tempo, como substitutivo da representação classista, que caracterizava a justiça paritária nos órgãos da Justiça do Trabalho, eliminada com a Emenda Constitucional $\mathrm{n}^{\mathrm{o}} 24$, de 9.12.99. Guarda semelhança com as comissões de empresa, há muitos anos em funcionamento nos países onde as relações de trabalho são mais desenvolvidas e que representam uma experiência exitosa para o seu ordenamento e solução dos litígios delas decorrentes.

Dois objetivos importantes podem ser alcançados com o correto funcionamento das Comissões de Conciliação Prévia: o primeiro, de política judiciária, pertinente à prevenção de ações judiciais, que tem o efeito de desafogar os órgãos do Judiciário Trabalhista, propiciando seu mais rápido e eficiente desempenho; o outro, de interesse social mais relevante, qual seja lograr a solução negociada dos litígios nas relações de trabalho, que, bem conduzida e havendo equilíbrio de forças entre os interlocutores, com a assistência sindical, representa a forma mais conveniente de dirimir tais litígios e mais apta a atingir a paz social, pela justa composição de interesses.

Parte-se do pressuposto de que a justiça promovida pelo Estado, conquanto indispensável, é insuficiente para satisfazer a crescente exigência da sociedade, em cujo seio se avolumam e se tornam cada dia mais complexos os litígios. A jurisdição estatal revela-se, há séculos, ineficiente para bem atender a essa demanda, especialmente no campo das relações negociais. Nesse contexto, aprofunda-se, pela experiência, a convicção de que a sociedade organizada é mais capaz de equacionar seus interesses e solucionar os conflitos a eles pertinentes. Busca-se, assim, uma gradativa substituição da Justiça Pública pela Justiça Privada, ou o reendereçamento do poder de distribuir justiça, como expressa José Washington Coelho (2000, pp. 3-4).

Como assinala Maurício Godinho Delgado (2002, p.663/670), o objetivo perquirido pela Lei ${ }^{\circ} 9.958 / 2000$ é semelhante ao pretendido pelos dispositivos que regem o arbitramento, em face do Direito Individual do Trabalho, ou seja, estabelecer mecanismo extrajudicial de solução de conflito decorrente da relação de emprego, sem observar princípio basilar do Direito do Trabalho. Segundo aquele jurista, a arbitragem nesse campo, prevista no art. $114, \S 2^{\circ}$, da $\mathrm{CF} / 88$, só é válida para dirimir conflito de natureza coletiva, "porque somente nesse plano é que podem existir garantias grupais necessárias para uma equânime distribuição de poder no âmbito dos sujeitos em conflito" (DELGADO, 
2002, p.669). Por conseguinte, faleceria às Comissões de Conciliação Prévia competência para intermediar a composição de litígio trabalhista de natureza individual (que é seu objetivo segundo a lei que as instituiu), visto que "a Carta Magna não conferiu, no plano juslaborativo, a qualquer entidade ou processo inerentes à sociedade civil, excetuada a negociação coletiva, poderes superiores aos restritos conferidos à transação meramente bilateral trabalhista" (DELGADO, 2002, p.670).

As Comissões de Conciliação Prévia representam uma solução modesta para a problemática trabalhista de nossos dias, tendo em vista a proposta feita pelo Tribunal Superior do Trabalho, que era em termos mais avançados. Receou-se enfrentamento de argüição de inconstitucionalidade, em face da cláusula pétrea (art. 60, $\S 4^{\circ}, \mathrm{IV}$, da CF/88) concernente aos dispositivos do art. $7^{\circ}$ da Constituição que só admitem transação extrajudicial acerca de direitos trabalhistas, com a intervenção de terceiro, mediante negociação coletiva, que requer a participação de sindicato. Porém, "o que tem de pequena e frágil na aparência, a Lei n. 9.958/2000 tem de grande e forte na substância" - diz José Washington Coelho (2000, p.5).

Tal órgão tem uma tarefa imensa e da mais alta relevância social: realizar justiça rápida, eficiente e barata. Pode ser instituído, tanto em empresas ou grupo de empresas, quanto em sindicatos ou grupos destes (comissões intersindicais), podendo os dispositivos da respectiva lei ser aplicados, no que couber, aos Núcleos Intersindicais de Conciliação Trabalhista, em funcionamento ou a serem criados.

A Comissão de Conciliação Prévia tem composição paritária, de representantes dos empregados e dos empregadores, e a atribuição de tentar conciliar os conflitos individuais do trabalho. Os representantes dos empregados membros da Comissão, titulares e suplentes, gozam de estabilidade temporária no emprego, que compreende o período do respectivo mandato mais 1 (um) ano após o término deste, salvo se cometerem falta grave, nos termos da lei; e terão computado como tempo de trabalho efetivo o despendido na atividade de conciliador.

A composição e as normas de funcionamento da Comissão instituída no âmbito do sindicato serão definidas em convenção ou acordo coletivo. Havendo na mesma localidade e para a mesma categoria Comissão de empresa e Comissão sindical, o interessado poderá optar por uma delas para submeter sua demanda, sendo competente aquela que primeiro conhecer do pedido.

Segundo o art. 625-D da CLT, o ajuizamento de reclamação trabalhista é condicionado à submissão prévia da demanda a uma Comissão de Conciliação Prévia que tiver sido instituída no local da prestação de serviços; e, somente em caso de frustração da tentativa de conciliação no referido órgão, ou em 
caso de motivo relevante que impossibilite o atendimento pela Comissão, é que se poderá recorrer ao Judiciário Trabalhista, devendo aquela circunstância ser declarada na petição inicial, com a juntada de declaração da tentativa conciliatória frustrada, se for o caso.

Estar-se-ia, aí, diante de cerceamento, ou restrição, do amplo acesso ao Judiciário, contrariando o princípio da inafastabilidade da jurisdição estatal (art. $5^{\circ}, \mathrm{XXXV}$ da CF/88). Isso leva a pressuposição de inconstitucionalidade da Lei $n^{\circ} 9.958 / 2000$.

Entretanto, ao ver do autor deste artigo, tal argumento não procede, porquanto não se impede o acesso ao Judiciário; apenas se requer medida prévia tendente à composição do litígio, que, sem dúvida, é a melhor forma de solução de conflito de interesses, qualquer que seja sua natureza, notadamente na seara trabalhista. Em outras situações, a própria Constituição ou a lei apresenta condição para o exercício do direito de ação, ou simplesmente o exclui. Citemse, como exemplos: a) a opção pelo arbitramento exclui a apreciação do seu objeto pelo Poder Judiciário (art. 267, VII, do CPC); o ajuizamento de dissídio coletivo, perante a Justiça do Trabalho, é condicionado a prévia tentativa de negociação, ou à arbitragem (art. 114, $\S 2^{\circ}$ da CF/88); b) nas lides sobre contrato de atleta profissional de futebol é imprescindível o esgotamento das vias administrativas, isto é, as instâncias da Justiça Desportiva (art. 29 da Lei $n^{\circ}$ 6.354/76), bem como, segundo o $\S 1^{\circ}$ do art 217 da $C F / 88$, em relação à disciplina e às competições desportivas em geral.

Dirimindo a controvérsia a esse respeito, o Supremo Tribunal Federal concedeu, em 13.5.2009, medida cautelar nas ADins n. 2.139-7 e 2.160-5, para dar interpretação conforme a Constituição ao art. 625-D da CLT, respeitado o princípio da inafastabilidade da jurisdição estatal (art. 5 $5^{\circ} \mathrm{XXX}$ da $\mathrm{CF} / 88$ ). Prevaleceu no excelso Pretório o entendimento de que a norma inscrita no art. 625-D da Consolidação não torna obrigatória a fase administrativa, pelo que continuam os titulares de direito substancial a ter acesso imediato ao Judiciário, desprezando a fase de atuação de Comissão de Conciliação Prévia. Assim, tal dispositivo deve ser interpretado como não impeditivo de ajuizamento de ação trabalhista sem anterior submissão da demanda a Comissão de Conciliação Prévia que houver sido instituída no local da prestação de serviços do demandante. Em outras palavras, não é mais condição para ajuizamento de reclamação trabalhista tal procedimento administrativo.

Havendo conciliação, será lavrado termo, assinado pelo empregado, pelo empregador ou seu preposto e pelos membros da Comissão, com cópia para as partes. O referido termo é título executivo extrajudicial e terá eficácia liberatória geral, exceto quanto às parcelas expressamente ressalvadas (art. 625E, § único). Sua execução faz-se na Justiça do Trabalho, independentemente 
da formação de prévio processo de conhecimento. Competente para tanto será o Juiz "que teria competência para o processo de conhecimento relativo à matéria" (art. 877-A, CLT).

\section{Conclusão}

$\mathrm{O}$ acesso à justiça é, como já assinalado, dever indeclinável do Estado para com os cidadãos. Não se concretiza com facilidade. Requer medidas inteligentes e hábeis, que dependem de vontade política e importam em despesas para o erário público.

Cumpre ao Estado disponibilizar a todos os cidadãos tal acesso, o que inclui a gratuidade do processo para os carentes de recursos econômicofinanceiros; bem assim reformar a estrutura dos órgãos jurisdicionais, modernizando-os, atualizando seu funcionamento e compatibilizando-os com a presteza e a eficiência que se requerem para a efetivação da justiça. Impõe-se, também, frequente revisão dos dispositivos legais respectivos, a fim de corrigir eventuais distorções que sua aplicação possa implicar e adaptá-los às circunstâncias emergentes, ante as constantes mutações e evolução das relações sociais.

No tocante aos mecanismos legais para lograr esse objetivo, o ordenamento jurídico brasileiro registra avanço significativo, com a instituição dos Juizados Especiais Cíveis e Criminais, Estaduais e Federais, assim como, no âmbito da Justiça do Trabalho, do procedimento sumaríssimo e das Comissões de Conciliação Prévia.

Restam, ainda, importantes providências a tomar, sem as quais se frustrará a regulamentação legal, dentre as quais, dotar os referidos órgãos dos meios materiais e humanos necessários para seu pleno e eficiente funcionamento, o que compete ao Poder Público. Outrossim, a participação dos operadores do direito é imprescindível para a efetiva aplicação das normas jurídicas e a efetivação dos direitos que elas consagram.

É o que se espera deles, como forma de honrar o compromisso assumido, de contribuir para a justiça social, que é pressuposto da paz e fundamento do bem comum. 


\section{REFERENCIAS}

BADARÓ, Marcelo Jodas. Jus Navigandi, O Juizado Especial Cível e a Comunidade. Teresina, ano 6, n. 51, 1 out. 2000. Disponível em: http:// www1.jus. com.br/doutrina/texto.asp?id=2129. Acessado em: 12.07.2012.

BARACHO, José Alfredo de Oliveira. Teoria Geral dos Procedimentos de Exercício da Cidadania perante a Administração Pública. In Revista Brasileira de Estudos Políticos, da Universidade Federal de Minas Gerais, Belo Horizonte, n.85, p.7-69, julho/97.

CAMPELO, Antônio de V. Coelho Barreto. Juizados Criminais Estaduais e Federais. Distinção dos conceitos de infração de menor potencial ofensivo. Inexistência de ofensa ao princípio constitucional da isonomia. In: NOGUEIRA FILHO, Rafael Ribeiro (Coord.). Temas de Processo Penal, vol. 2. Coletânea de Trabalhos Jurídicos. Fortaleza DIN-CE, 2002.

DELGADO, Maurício Godinho. Arbitragem, Mediação e Comissão de Conciliação Prévia no Direito do Trabalho brasileiro. In: Revista LTr Legislação do Trabalho, São Paulo, ano 66, p. 663-670, junho/2002.

COELHO, José Washington. Conciliação prévia- Função de natureza pública exercida por instituição privada. São Paulo: LTr Edit., 2000.

MARTINI, Paulo. A não aplicação da Lei no 10.259/01 no âmbito estadual. Jus Navigandi, Teresina, ano 7, n. 56, 1 abr. 2002. Disponível em: http://jus.com.br/ revista/texto/2892. Acessado em: 13.07.2012.

NERY JR., Nelson. Princípios do Processo Civil na Constituição Federal. São Paulo: Revista dos Tribunais, 1995.

OLIVEIRA, Francisco Antônio de. Do rito sumaríssimo - Lei no 9.957, de 12.01.2000. In Revista da AMATRA II, São Paulo, ano I, nº 2, abril de 2000.

PROVINCIALI, Renzo. Norme di diritto processuale nella costituzione. In Università di Catania. Milano: Dott. A. Guiffrè - Editore, 1959.

ROSAS, Roberto.Direito Processual Constitucional-Princípios Constitucionais do Processo Civil. São Paulo: Edit. Rev dos Tribunais, 1999. 
SILVA, Danni Sales. Novas interpretações da Lei n ${ }^{\circ}$ 9.099/95, ante o advento da Lei do Juizados Especiais Criminal na Justiça Federal (Lei no 10.259/01). Jus Navigandi, Teresina, ano 7, n. 54, 1 fev. 2002. Disponível em: http://jus.com.br/ revista/texto/2716. Acessado em: 12.07.2012.

TEIXEIRA, Manuel Antônio. O Procedimento Sumaríssimo no Processo do Trabalho - Comentários à Lei ${ }^{\circ}$ 9.957/2000. São Paulo: LTr Editora Ltda., 2000 .

TOURINHO NETO, Fernando da Costa. Juizados Especiais Federais. Jus Navigandi, Teresina, ano 6, n. 51, 1 out. 2001. Disponível em: http://jus.com.br/ revista/texto/2230. Acessado em: 12.07.2012. 